\title{
Oxidative Thermal Sintering and Redispersion of Rh Nanoparticles on Supports with High Oxygen Ion Lability
}

\author{
Grammatiki Goula ${ }^{1}\left(\right.$, Georgia Botzolaki ${ }^{1}$, Amin Osatiashtiani ${ }^{2}{ }^{\circledR}$, \\ Christopher M. A. Parlett ${ }^{3,4}{ }^{\mathbb{D}}$, Georgios Kyriakou ${ }^{2,5}{ }^{(D}$, Richard M. Lambert ${ }^{6}$ and \\ Ioannis V. Yentekakis $1, *$ (D) \\ 1 Laboratory of Physical Chemistry \& Chemical Processes (www.pccplab.tuc.gr), School of Environmental \\ Engineering, Technical University of Crete, GR-73100 Chania, Greece; mgoula@science.tuc.gr (G.G.); \\ gmpotzolaki@isc.tuc.gr (G.B.) \\ 2 European Bioenergy Research Institute, Aston University, Aston Triangle, Birmingham B4 7ET, UK; \\ a.osatiashtiani@aston.ac.uk (A.O.); kyriakg@upatras.gr (G.K.) \\ 3 The School of Chemical Engineering and Analytical Science, The University of Manchester, Manchester \\ M13 9PL, UK; Christopher.parlett@manchester.ac.uk \\ 4 Diamond Light Source, Harwell Campus, The University of Manchester at Harwell, Didcot OX11 0DE, UK \\ 5 Department of Chemical Engineering, University of Patras, GR-26500 Patras, Greece \\ 6 Department of Chemistry, Cambridge University, Cambridge CB2 1EW, UK; rml1@cam.ac.uk \\ * Correspondence: yyentek@isc.tuc.gr
}

Received: 21 May 2019; Accepted: 11 June 2019; Published: 17 June 2019

\begin{abstract}
The thermal sintering under oxidative conditions of Rh nanoparticles supported on oxides characterized by very different oxygen storage capacities (OSC) and labilities was studied at 750 and $850{ }^{\circ} \mathrm{C}$. Under sintering conditions, significant particle growth occurred for $\mathrm{Rh} / \gamma-\mathrm{Al}_{2} \mathrm{O}_{3}$ (up to $120 \%$ at $850^{\circ} \mathrm{C}$ ). In striking contrast, $\mathrm{Rh} / \mathrm{ACZ}$ (alumina-ceria-zirconia) and $\mathrm{Rh} / \mathrm{CZ}$ (ceria-zirconia) exhibited marked resistance to sintering, and even moderate (ca. $-10 \%$ at $850{ }^{\circ} \mathrm{C}$ ) to pronounced (ca. $-60 \%$ at $850^{\circ} \mathrm{C}$ ) redispersion of the Rh. A model is proposed based on a double-layer description of metal-support interactions assigned to back-spillover of labile oxygen ions onto the Rh particles, accompanied by trapping of atomic Rh by the resulting surface oxygen vacancies. This model accounts for the observed resistance to sintering and actual redispersion of Rh, consistent with both alternative sintering mechanisms, namely Ostwald ripening (OR) or particle migration and coalescence (PMC).
\end{abstract}

Keywords: rhodium; alumina ceria zirconia; nanoparticles sintering; redispersion; oxygen storage capacity; atom trapping; Ostwald ripening; particle migration and coalescence; metal-support interactions

\section{Introduction}

The vast majority of commercial heterogeneous catalysts consist of metal nanoparticles (NPs) supported on oxides, mixed oxides or other high-surface-area materials. Restricting the active phases to the nanoscale maximizes both the number of active catalytic sites and the interaction area between the active phase and the supports [1,2]. The former provides efficient utilization of scarce and expensive platinum group metals (PGMs) whilst the latter commonly leads to beneficial promotional effects on catalytic performance for a range of reactions resulting from the so-called metal-support interaction [3-10]. Major advances in nanocatalysis have been achieved recently due to the advent of new or optimized traditional synthesis routes that enable the deposition of NPs with very narrow particle size distributions, even to the level of atomic dispersion [1,2,11-15]. 
However, deterioration of catalytic performance via thermal agglomeration under typical operating conditions or during regeneration remains a key problem that has received much attention both for reasons of fundamental significance and practical importance [16-21]. It is a leading cause of the degradation of industrial catalysts used for large-scale synthesis of commodity chemicals as well as energy and environmental catalytic applications that operate at elevated temperatures.

Up to date accounts of the mechanisms invoked are available in the comprehensive reviews of Dai et al. [18], Goodman et al. [19] and Hansen et al. [20]. There are two main categories (Figure 1): Either migration of entire nanoparticles and subsequent coalescence (PMC); or net transport of single atomic species from smaller to larger nanoparticles so-called atomic ripening (AR), which includes the particular case of Ostwald ripening (OR) (path b in Figure 1)-AR refers to any path of atom migration, either over the surface of the support, or via the vapor phase [19]. Traditional analyses (e.g., ex situ transmission electron microscopy (TEM)) of samples subjected to a variety of sintering protocols makes distinguishing between OR and PMC a nontrivial and often impossible issue. Modes of sintering are strongly dependent on the metal-support couple under consideration, as well as on the reaction conditions and temperature. Modern state-of-the-art in situ TEM techniques have greatly increased our knowledge, providing clear evidence that OR is the dominant mechanism in some specific catalytic systems [22,23]. On the other hand, very recent literature points to the importance of PMC in controlling sintering of dispersed nanoparticles. Thus, by means of precise atomic layer deposition and modeling, Grillo et al. $[14,15]$ demonstrated that NPs grew mainly via particle migration and coalescence (PMC) rather than by OR. They claimed that OR of supported noble metals NPs is a slow process that typically dominates the late stages of growth of large immobile NPs (ca. $>5 \mathrm{~nm}$ ) at high temperatures $\left(400-1000^{\circ} \mathrm{C}\right)$ and over long time scales (hours to years) [14].

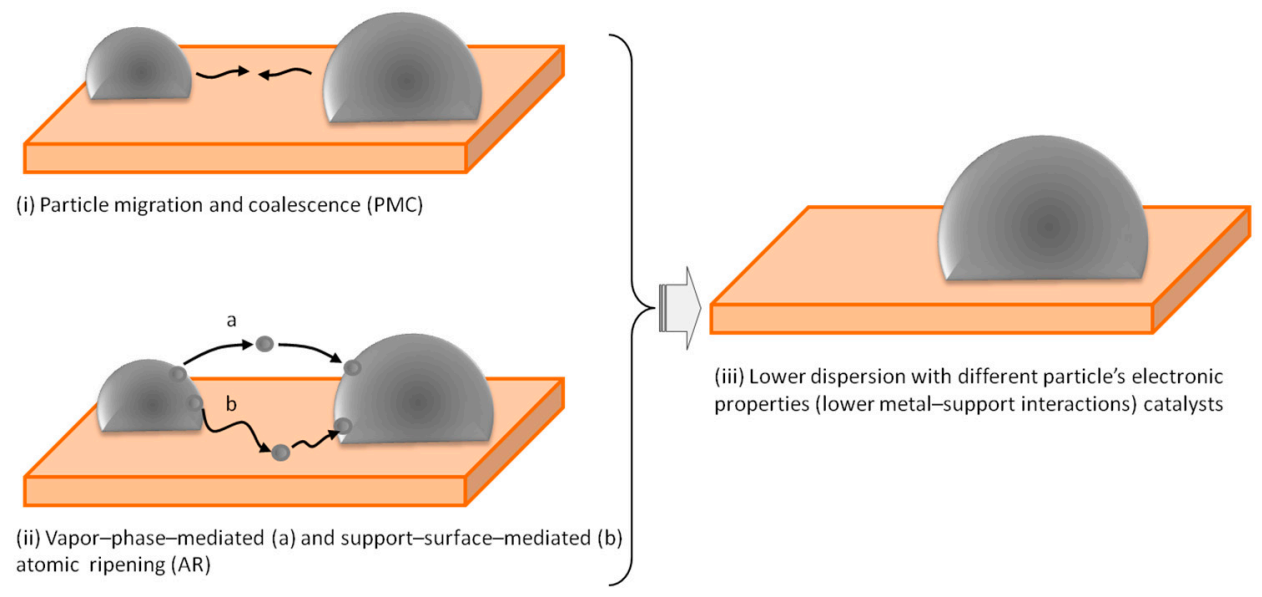

Figure 1. Schematic of potential sintering mechanisms of catalytic nanoparticles leading to sintering, fewer undercoordinated sites and reduced metal-support interaction.

Since all heterogeneous catalysts are inevitably subjected to sintering during operation and regeneration [16,21], regardless of mechanism, the effect poses a grand challenge for the development of sinter-resistant catalysts $[18,19]$. Both PMC and OR mechanisms require the breaking of bonds between metal atoms and between metal atoms and the support surface, so that sintering is always a strong function of temperature. The characteristic temperatures for atom detachment and their subsequent diffusion can be estimated from the respective Hütting and Tamman temperatures $\left(\mathrm{T}_{\mathrm{H}}=0.3 \mathrm{~T}_{\text {melting, }}, \mathrm{T}_{\mathrm{T}}=0.5 \mathrm{~T}_{\text {melting }}\right)[16,21]$ which provide an indication of the temperatures at which surface and bulk atoms are mobilized. Indeed, the susceptibilities to sintering of some common heterogeneous catalysts in their metallic state (under reducing atmosphere) are in accordance with their $T_{H}$ and $T_{T}$ temperatures: Nanoparticle stability generally decreases with decreasing $T_{H}$ and $\mathrm{T}_{\mathrm{T}}$ temperatures in the sequence: $\mathrm{Ru}>\mathrm{Ir}>\mathrm{Rh}>\mathrm{Pt}>\mathrm{Pd}>\mathrm{Ni}>\mathrm{Cu}>\mathrm{Ag}$ [21]. The actual order is, of course, subject to metal-support adhesion energy and possible strong interactions that can 
influence behavior in many practical catalyst systems. In oxidizing atmospheres, $\mathrm{T}_{\mathrm{H}}$ and $\mathrm{T}_{\mathrm{T}}$ are of much less use for the prediction of nanoparticle stability which also depends on their volatility, thermal stability (some metal oxides decompose before $\mathrm{T}_{\mathrm{H}}$ or $\mathrm{T}_{\mathrm{T}}$ are reached) and the strength of the metal-oxide-support interaction [16,21]. Indeed, for PGMs dispersed on a relatively inert support $\left(\gamma-\mathrm{Al}_{2} \mathrm{O}_{3}\right)$ Fiedorow et al. [24] obtained the following stability sequence in oxidizing atmospheres $\mathrm{Rh}>$ $\mathrm{Pt}>\mathrm{Ir}>\mathrm{Ru}$, which does not match the order indicated by the $\mathrm{T}_{\mathrm{T}}$ of the corresponding PGM oxides $\left(\mathrm{RuO}_{2}(735 \mathrm{~K}), \mathrm{Rh}_{2} \mathrm{O}_{3}(687 \mathrm{~K}), \mathrm{IrO}_{2}(685 \mathrm{~K}), \mathrm{PtO}_{2}(362 \mathrm{~K})\right)$. However, under reducing conditions (NPs in the metallic state), the stability sequence was $\operatorname{Ir} \sim \mathrm{Ru}>\mathrm{Rh}>\mathrm{Pt}$ in agreement with their $\mathrm{T}_{\mathrm{T}}$ values.

As noted above, metal-support interactions may drastically alter such simplified predictions. Accordingly, strategies that involve enhancement of the interaction of NPs with the supports have often been used in efforts aimed at designing sinter-resistant catalysts; a comprehensive tutorial review by Dai et al. [18] is available. In this respect, atom trapping, i.e., immobilization of isolated single atoms at support sites is a new and promising approach, especially with supports that provide surface lattice oxygen defects that could act as trapping centers [11-13]. $\mathrm{CeO}_{2}-$ and $\mathrm{ZrO}_{2}$-based materials and perovskites that contain a sufficient concentration of surface and bulk oxygen vacancies can provide traps for metal atoms during their diffusion and indeed have been successfully used for this purpose [8,25-29].

Atom trapping methodology may also be used to induce on-stream redispersion of catalyst particles by applying oxidizing conditions at a high temperature [11]. This is of major importance in the chemical industry and studies involving redispersion of PGM nanoparticles, mainly Pt, have recently appeared [13,30-32]. In the absence of trapping centers, high-temperature oxidative treatment inevitably leads to particle agglomeration. Fewer studies on the sintering behavior of other PGMs have appeared, Ir [8,27,28], Pd [29], and Rh [33-36]. Notably, and of direct relevance to the present paper, reports on their potential for in situ redispersion are absent.

Here, we report the resistance, or lack of resistance, to sintering and also the in situ on-stream high-temperature oxidative redispersion of Rh nanoparticles deposited on oxide supports encompassing a wide range of lattice oxygen ion lability, namely $\gamma-\mathrm{Al}_{2} \mathrm{O}_{3}$, alumina-ceria-zirconia (ACZ: $80 \mathrm{wt} \%$ $\mathrm{Al}_{2} \mathrm{O}_{3}-20 \mathrm{wt} \% \mathrm{Ce}_{0.5} \mathrm{Zr}_{0.5} \mathrm{O}_{2-\delta}$ ) and ceria-zirconia ( $\left.\mathrm{CZ}: \mathrm{Ce}_{0.5} \mathrm{Zr}_{0.5} \mathrm{O}_{2-\delta}\right)$ supports. It is found that the higher the oxygen ion lability of the support, the lower the propensity of the nanoparticles to sintering, and most importantly, the higher the propensity towards redispersion at high temperatures. The sintering model recently developed by our group $[8,27,28]$ explains the observed behavior in terms of both OR and PMC mechanisms. As we shall see, it also provides a satisfactory explanation of the redispersion phenomena found here. To the best of our knowledge, this is the first report of Rh redispersion achieved by a simple in situ and cost-effective atomic trapping methodology.

\section{Results and Discussion}

\subsection{Materials Characterization}

\subsubsection{Textural Characteristics}

The pore size distributions of the $\gamma-\mathrm{Al}_{2} \mathrm{O}_{3}, \mathrm{ACZ}$ and $\mathrm{CZ}$ supports and the corresponding $\mathrm{Rh} / \gamma-\mathrm{Al}_{2} \mathrm{O}_{3}, \mathrm{Rh} / \mathrm{ACZ}$ and $\mathrm{Rh} / \mathrm{CZ}$ catalysts are shown in Figure 2; the insets depict the corresponding $\mathrm{N}_{2}$ adsorption-desorption isotherms at $-196^{\circ} \mathrm{C} . \gamma-\mathrm{Al}_{2} \mathrm{O}_{3}$ and $\mathrm{Rh} / \gamma-\mathrm{Al}_{2} \mathrm{O}_{3}$ exhibited type IV isotherms similar to mesoporous oxides according to IUPAC classification, with a $\mathrm{H} 1$ hysteresis loop suggesting a channel-like structure with spherical or cylindrical mesopores [37]. The isotherms did not show a distinct plateau at $0.8<\mathrm{P} / \mathrm{P}_{\mathrm{o}}<1$ probably due to the presence of macroporosity and interparticle porosity. On the other hand, the absence of the characteristic steep rise at the beginning of the absorption branch suggests the absence of micropores. The calculated pore size distribution (PSD) using the Barrett-Joyner-Halenda (BJH) model showed two distributions of mesopores with diameters $\sim 10$ and $\sim 15 \mathrm{~nm}$, respectively. In a similar manner the $\mathrm{ACZ}$ and $\mathrm{Rh} / \mathrm{ACZ}$ isotherms may be identified as type IV with $\mathrm{H} 1$ tending to $\mathrm{H} 2$-type hysteresis, characteristic of cylindrical and cylindrical-ink-bottle 
pores with a fairly narrow unimodal pore-size distribution of $\sim 8 \mathrm{~nm}$ diameter. This is in accord with Brunauer-Emmett-Teller (BET)-BJH results reported for similar materials [38]. CZ and Rh/CZ yield type IV isotherms with $\mathrm{H} 2$-like hysteresis attributed to cylindrical-ink-bottle pores with principal distribution centered at $\sim 9 \mathrm{~nm}$ diameter, characteristics in agreement with literature data $[39,40]$.
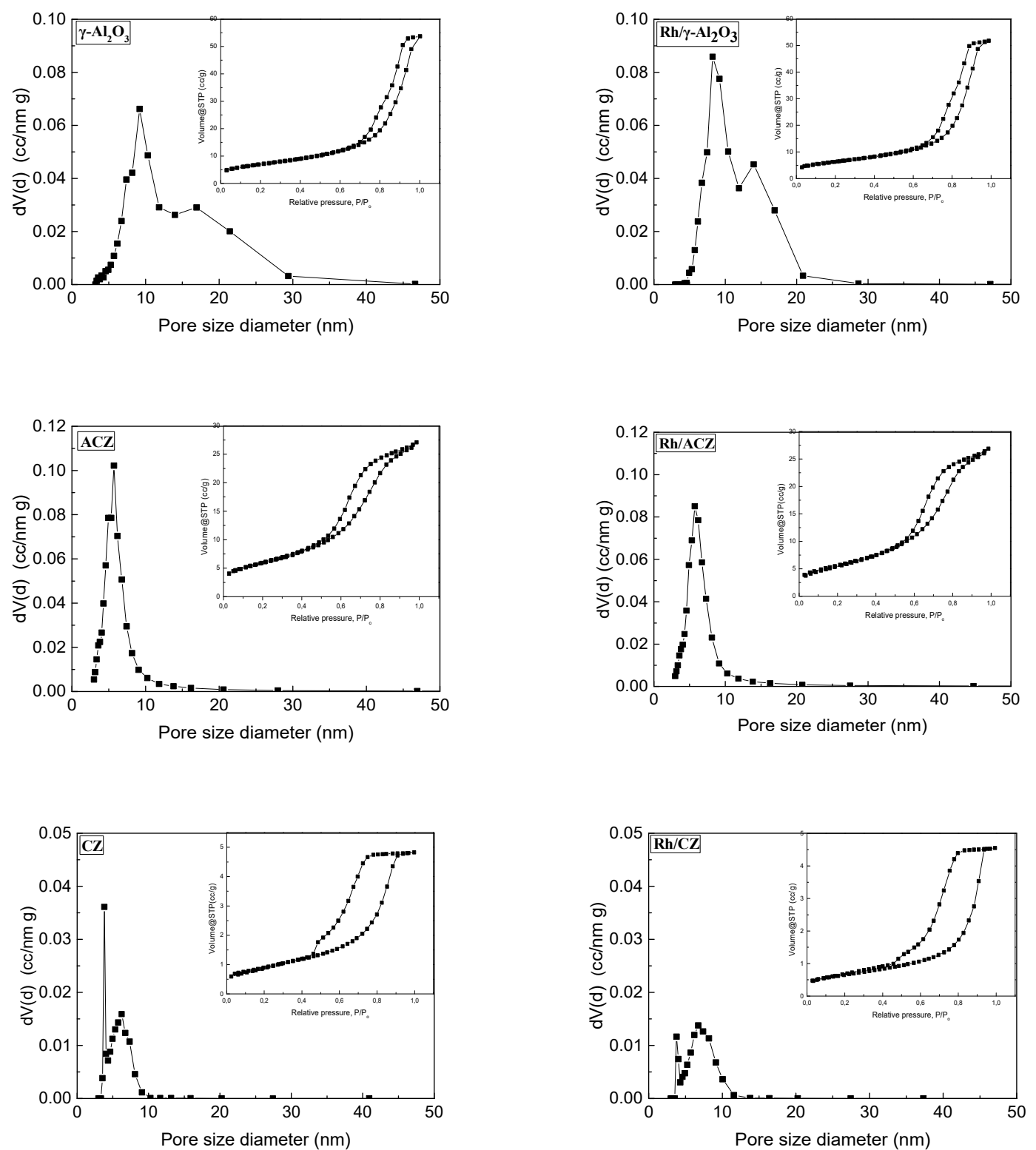

Figure 2. Pore size distribution and $\mathrm{N}_{2}$ adsorption-desorption isotherms (inset) of the support materials and the corresponding Rh catalysts. ACZ: Alumina-ceria-zirconia; CZ: Ceria-zirconia.

The textural characteristics of the supports and the corresponding Rh catalysts, obtained by means of the BET-BJH method, are summarized in Table 1. It is apparent that differences between the textural characteristics of the supports and the corresponding catalysts are marginal; the small decreases in the total surface areas and pore volumes between pristine supports and the counterpart Rh catalysts indicates the expected presence of some mesopore blocking by the metal particles. The table also includes the inductively coupled plasma-optical emission spectroscopy (ICP-OES) determined Rh loadings of the three catalysts. For $\mathrm{Rh} / \gamma-\mathrm{Al}_{2} \mathrm{O}_{3}$, it was $1 \mathrm{wt} \%$, corresponding to the nominal expected value; slightly lower on $\mathrm{Rh} / \mathrm{ACZ}$ and $\mathrm{Rh} / \mathrm{CZ}(0.8 \mathrm{wt} \%)$. 


\subsubsection{Reducibility Characteristics}

Figure 3 depicts the $\mathrm{H}_{2}$ consumption profiles of the supports (Figure $3 \mathrm{a}$ ) and the Rh catalyst counterparts (Figure $3 b$ ) obtained by temperature programmed reduction with hydrogen $\left(\mathrm{H}_{2}-\mathrm{TPR}\right)$ experiments. Since our attention is focused on the amount of labile lattice oxygen in these materials, the discussion below provides this quantity in $\mu \mathrm{mol} \mathrm{O}_{2}$ per gram of material, which corresponds to half of the amount of consumed $\mathrm{H}_{2}$. The oxygen storage capacities for both supports and catalysts assessed by $\mathrm{H}_{2}$-TPR (Figure 3) are included in Table 1 . The values of 0,101 and $557 \mu \mathrm{mol} \mathrm{O}_{2} \mathrm{~g}^{-1}$ for the $\gamma-\mathrm{Al}_{2} \mathrm{O}_{3}, \mathrm{ACZ}$ and $\mathrm{CZ}$ supports, respectively, reflect the nonreducible character of $\gamma-\mathrm{Al}_{2} \mathrm{O}_{3}$, and the $\mathrm{Ce}^{4+} \rightarrow \mathrm{Ce}^{3+}$ reduction of $\mathrm{ACZ}$ and $\mathrm{CZ}$ supports giving rise in the latter cases to two broad overlapping peaks at ca. $450-500{ }^{\circ} \mathrm{C}$ and $650-700{ }^{\circ} \mathrm{C}$ (Figure 3a). This is a feature characteristic of ceria-containing samples [41,42]; the low-temperature (LT) peak is attributed to superficial reduction taking place at CZ surfaces, whilst the high-temperature (HT) one is assigned to reduction of bulk ceria [41].

Dispersion of $\sim 1 \mathrm{wt} \% \mathrm{Rh}$ on the supports resulted in an increase in the hydrogen consumption, thus in oxygen capacity, for all three cases, yielding respectively 70, 146 and $589 \mu \mathrm{mol} \mathrm{O} \mathrm{g}^{-1}$ values for $\mathrm{Rh} / \gamma-\mathrm{Al}_{2} \mathrm{O}_{3}, \mathrm{Rh} / \mathrm{ACZ}$ and $\mathrm{Rh} / \mathrm{CZ}$. These higher values compared to the corresponding values (i.e., 0 , 101 and $557 \mu \mathrm{mol} \mathrm{O}_{2} \mathrm{~g}^{-1}$ ) for the $\gamma-\mathrm{Al}_{2} \mathrm{O}_{3}, \mathrm{ACZ}$ and $\mathrm{CZ}$ supports, respectively, reflect the contribution of rhodium oxide reduction to the metallic phase. Specifically, for $\mathrm{Rh} / \gamma-\mathrm{Al}_{2} \mathrm{O}_{3}$, the peak at ca. $150{ }^{\circ} \mathrm{C}$ and a broader one at ca. $500{ }^{\circ} \mathrm{C}$, corresponding to 45 and $25 \mu \mathrm{mol} \mathrm{O} \mathrm{O}^{-1}$, respectively, due to rhodium oxide reduction, are equivalent to a total of $70 \mu \mathrm{mol} \mathrm{O} \mathrm{g}^{-1}$, which is very close to the theoretically calculated amount of $73 \mu \mathrm{mol} \mathrm{O} \mathrm{g}^{-1}$ for $\mathrm{Rh}_{2} \mathrm{O}_{3} \rightarrow \mathrm{Rh}^{0}$ reduction with $1 \mathrm{wt} \% \mathrm{Rh}$ in the catalyst. The LT peak $\left(\sim 150^{\circ} \mathrm{C}\right)$ can be attributed to reduction of $\mathrm{Rh}_{2} \mathrm{O}_{3}$ species on the alumina surface, while the broad HT peak $\left(\sim 500{ }^{\circ} \mathrm{C}\right)$ could originate from reduction of $\mathrm{RhAl}_{\mathrm{x}} \mathrm{O}_{\mathrm{y}}$ formed at the metal-support interface by diffusion of rhodium oxide into the alumina, as reported in the literature [36]. The $\mathrm{Rh}$ oxide reduction peaks for both $\mathrm{Rh} / \mathrm{ACZ}$ and $\mathrm{Rh} / \mathrm{CZ}$ appear at a much lower temperature $\left(\mathrm{ca} .90^{\circ} \mathrm{C}\right.$ ) compared to $\mathrm{Rh} / \gamma-\mathrm{Al}_{2} \mathrm{O}_{3}$. This is due to hydrogen spillover that promotes the reducibility of both $\mathrm{CeO}_{2}$ and $\mathrm{Rh}_{2} \mathrm{O}_{3}[7,41,42]$. The oxygen capacities corresponding to Rh oxide reduction on $\mathrm{Rh} / \mathrm{ACZ}$ and $\mathrm{Rh} / \mathrm{CZ}$ were 45 and $32 \mu \mathrm{mol} \mathrm{O} \mathrm{g}^{-1}$, respectively, i.e., both significantly lower than $58.4 \mu \mathrm{mol} \mathrm{O} \mathrm{g}^{-1}$ calculated theoretically for these samples containing $0.8 \mathrm{wt} \% \mathrm{Rh}$.

This is in agreement with our recent results which demonstrated that rhodium nanoparticles anchored on supports with high oxygen ions lability undergo only partial oxidation because strong interactions with these supports destabilizes the Rh oxide phase [43]. In particular, the capacity of $32 \mu \mathrm{mol} \mathrm{O} \mathrm{O}^{-1}$ found for $\mathrm{Rh} / \mathrm{CZ}$, where all $\mathrm{Rh}$ particles are in interaction with $\mathrm{CZ}$, is close to the theoretical value of 29.2 which corresponds to the transformation of $\mathrm{Rh}^{1+} \rightarrow \mathrm{Rh}^{0}$. This is in good agreement with our recent X-ray photoelectron spectroscopy (XPS) findings, which showed that $\mathrm{Rh}^{1+}$ was the only metal phase present on preoxidized $\mathrm{Rh} / \mathrm{CZ}$ resulting from extensive $\mathrm{O}^{2-}$ back-spillover from the $\mathrm{CZ}$ support to Rh particles, thus weakening the Rh-O bond and destabilizing the $\mathrm{Rh}_{2} \mathrm{O}_{3}$ phase [43]. At the same time, the enhanced reducibility of $\mathrm{ACZ}$ and $\mathrm{CZ}$ is evidenced by the substantial shift of the peaks attributed to ceria reduction to lower temperature (ca. $150-450{ }^{\circ} \mathrm{C}$, Figure $3 b$ ) indicating strong promotion of $\mathrm{H}_{2}$ spillover, which, in the absence of metal, is limited by $\mathrm{H}_{2}$ dissociation [41,42].

\subsubsection{Structural and Morphological Characteristics}

Powder X-ray diffraction (PXRD) data for the fresh $\mathrm{Rh} / \gamma-\mathrm{Al}_{2} \mathrm{O}_{3}, \mathrm{Rh} / \mathrm{ACZ}$ and $\mathrm{Rh} / \mathrm{CZ}$ catalysts [43] showed no diffraction peaks corresponding to $\mathrm{Rh}$ due to the small metal particle size $(<\sim 5 \mathrm{~nm})$, as indeed confirmed by the $\mathrm{H}_{2}$ titration data (Table 2); $\mathrm{Rh}$ nanoparticles were, however, visible by high-resolution transmission electron microscopy (HRTEM) as shown below. Characteristic reflections of a $\mathrm{Ce}_{0.5} \mathrm{Zr}_{0.5} \mathrm{O}_{2-\delta}$ solid solution were detected in the $\mathrm{CZ}$-containing samples ( $\mathrm{Rh} / \mathrm{ACZ}$ and $\mathrm{Rh} / \mathrm{CZ}$ ). Also observed in the Rh/ACZ catalyst were distinct phases of $\gamma-\mathrm{Al}_{2} \mathrm{O}_{3}$ and $\mathrm{CZ}$, consistent with a mutual partial coating of the two substances at the nanometer scale, in accord with the literature for ACZ mixed oxides prepared by a similar method $[7,44,45]$. Since the percentage of the $C Z$ component 
in $\mathrm{ACZ}$ support is low $(20 \%), \gamma-\mathrm{Al}_{2} \mathrm{O}_{3}$ is expected to predominate at the surface-the so-called "alumina diffusion-barrier" [44] characteristic of ACZ composites synthesized as here-which inhibits segregation of alumina and $\mathrm{CZ}$ phases at elevated temperatures, thus preventing sintering of noble metal nanoparticles.
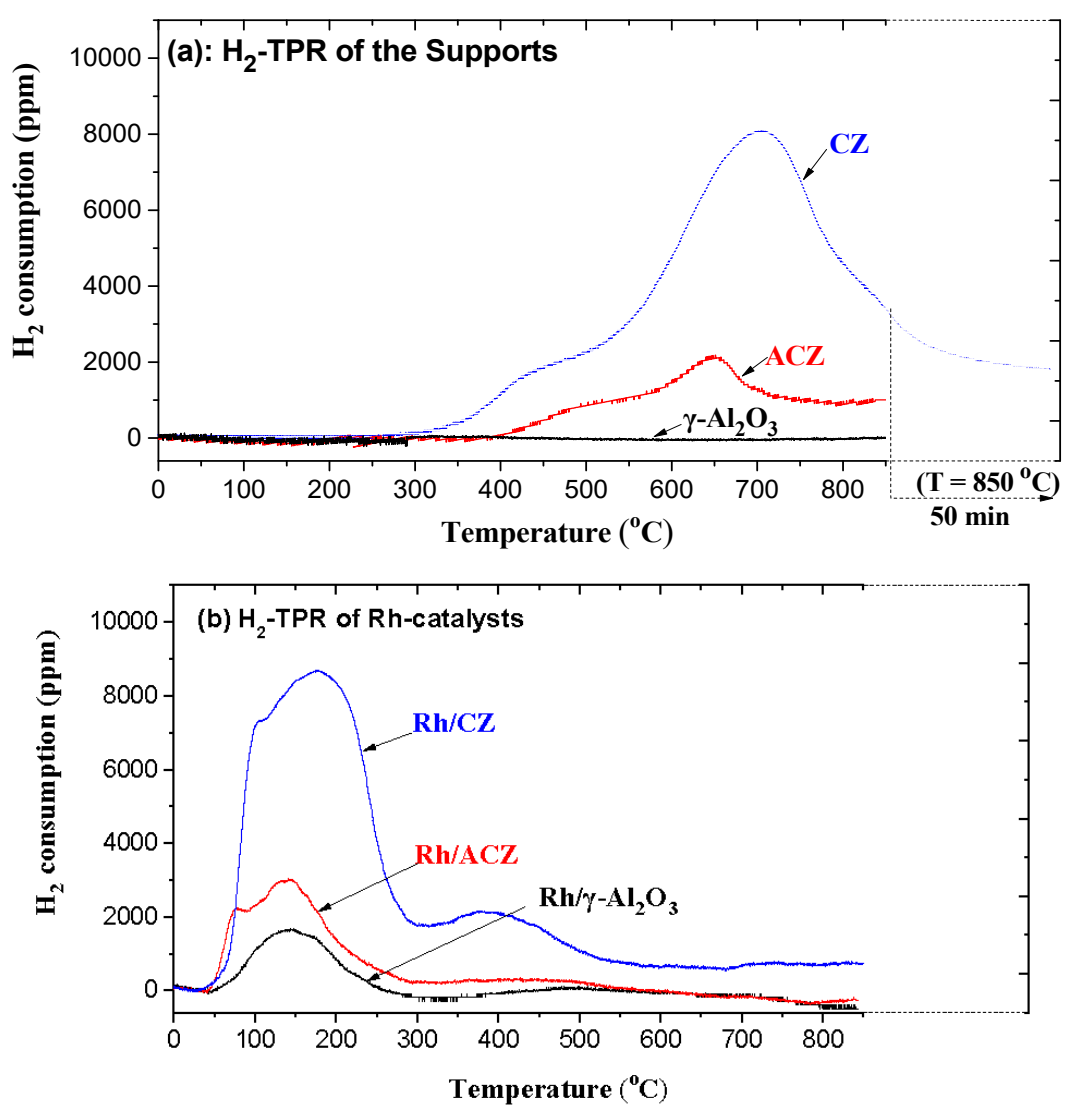

Figure 3. $\mathrm{H}_{2}-\mathrm{TPR}$ profiles of (a) the $\gamma-\mathrm{Al}_{2} \mathrm{O}_{3}, \mathrm{ACZ}$ and $\mathrm{CZ}$ supports and (b) the corresponding Rh catalysts.

Table 1. Textural characteristics and oxygen storage capacities (OSC) of the support materials and the corresponding fresh Rh catalysts.

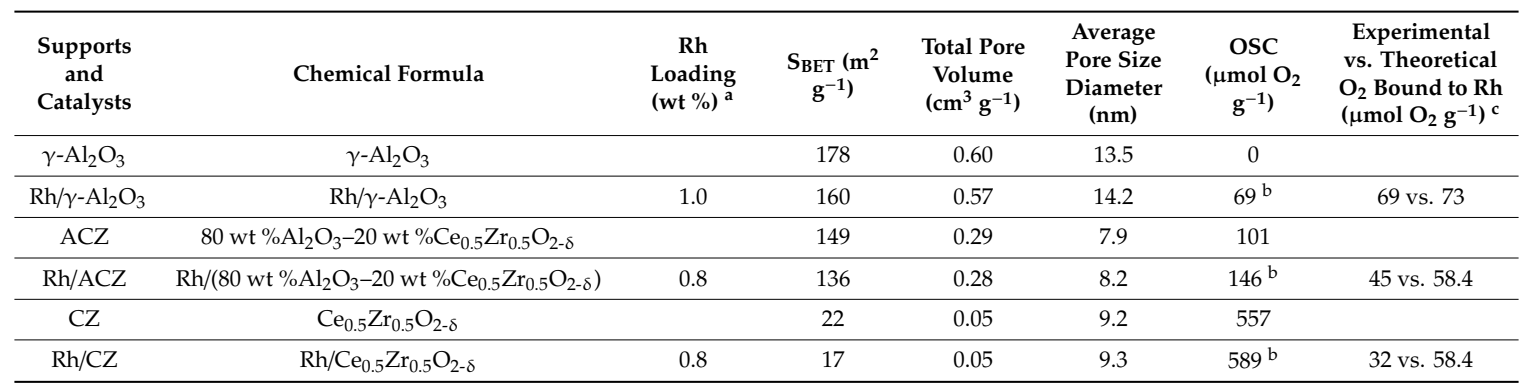

${ }^{\mathbf{a}} \mathrm{Rh}$ content measured by means of inductively coupled plasma-optical emission spectroscopy (ICP-OES). ${ }^{\mathbf{b}}$ These values include the amount of oxygen bound to the $\mathrm{Rh}$ component of the sample as rhodium oxides (i.e., the $\mathrm{O}_{2}$ amount related to the transformation $\mathrm{Rh}$ oxides $\left.\rightarrow \mathrm{Rh}^{0}\right)$. ${ }^{\mathrm{c}}$ These values compare the experimentally measured (via $\mathrm{H}_{2}$-TPR) amount of oxygen bound to the $\mathrm{Rh}$ component of the catalysts as rhodium oxide species versus the theoretically calculated amount of oxygen bound to the Rh component of the catalysts as $\mathrm{Rh}_{2} \mathrm{O}_{3}$.

Figure $4 \mathrm{~A}$ shows representative HRTEM images and corresponding particle size distributions for the three freshly prepared catalysts (a) $\mathrm{Rh} / \gamma-\mathrm{Al}_{2} \mathrm{O}_{3}$, (b) $\mathrm{Rh} / \mathrm{ACZ}$ and (c) $\mathrm{Rh} / \mathrm{CZ}$ which exhibited small randomly distributed spherical metal particles of $1.3 \pm 0.4,1.5 \pm 0.5$ and $5.1 \pm 1.7$, respectively 
(Figure $4 \mathrm{~A}(\mathrm{a}, \mathrm{b}, \mathrm{c})$ and Table 2). Oxidative sintering in $20 \% \mathrm{O}_{2} / \mathrm{He}$ flow at $750{ }^{\circ} \mathrm{C}$ for $2 \mathrm{~h}$ (Sinter \#1, Figure $4 \mathrm{~B}$ ), followed by additional sintering in the same environment at $850{ }^{\circ} \mathrm{C}$ for $2 \mathrm{~h}$ (Sinter \#2, Figure 4C) caused significant changes in the mean Rh particle size distribution (though not in particle shape). This implies the simultaneous occurrence of both particle growth and particle redispersion whose relative importance depends strongly on the identity of the supporting material, as discussed in detail below.

(A) Fresh samples
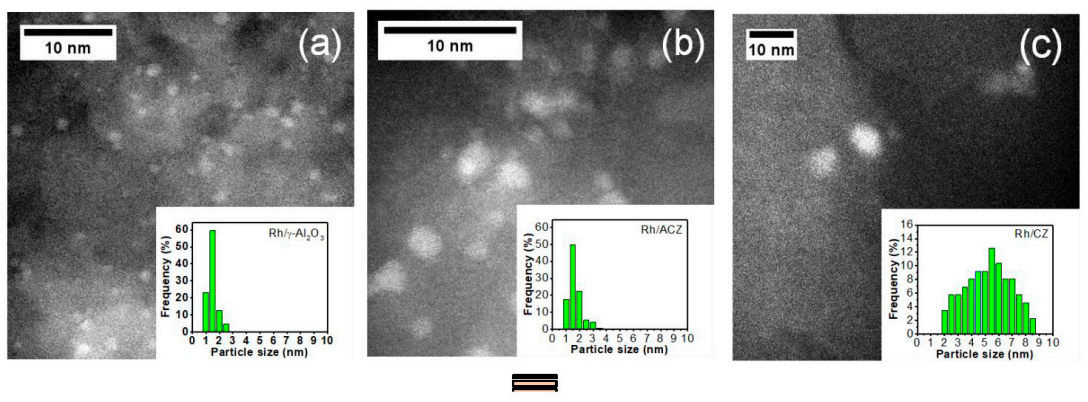

Oxidative Sintering at $750^{\circ} \mathrm{C}(2 \mathrm{~h}$

$\overbrace{\text { ter } \# 1 \text { samples }}$
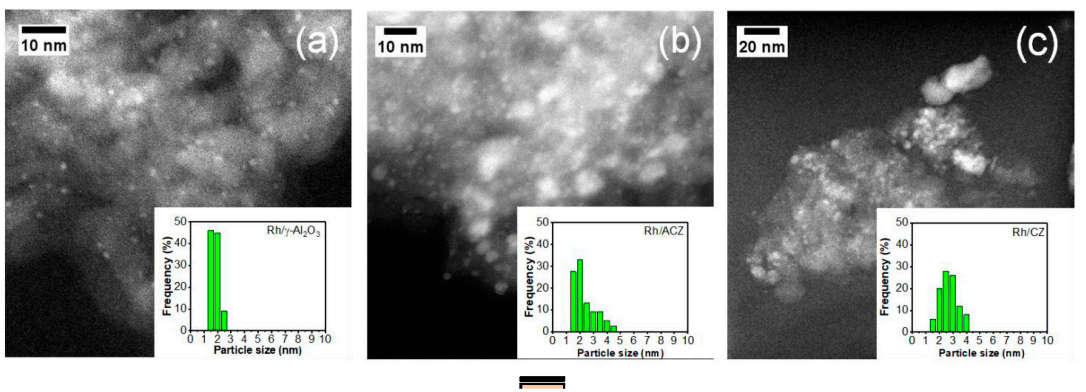

Oxidative Sintering at $750^{\circ} \mathrm{C}(2 \mathrm{~h})+850^{\circ} \mathrm{C}(2 \mathrm{~h})$

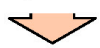

(C) Sinter \#2 samples
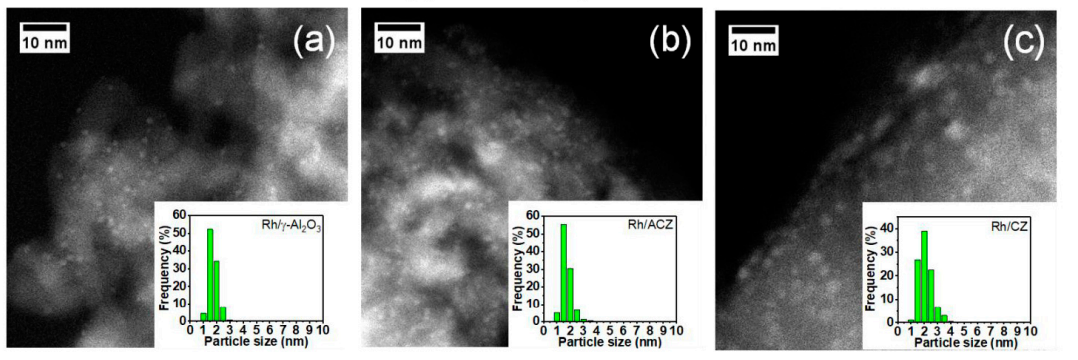

Figure 4. High-resolution transmission electron microscopy (HRTEM) images and particle size distributions of (A) fresh, (B) Sinter \#1 and (C) Sinter \#2 (a) $\mathrm{Rh} / \gamma-\mathrm{Al}_{2} \mathrm{O}_{3}$, (b) $\mathrm{Rh} / \mathrm{ACZ}$ and (c) $\mathrm{Rh} / \mathrm{CZ}$ catalysts.

\subsection{Sintering Behavior}

Sintering of $\mathrm{Rh}$ nanoparticles on the three supports was investigated by means of $\mathrm{H}_{2}$-chemisorption $\left(\mathrm{H}_{2}\right.$-uptake data shown in Supplementary Material, Table S1), and corroborated by HRTEM measurements on the (A) fresh, (B) Sinter \#1 and (C) Sinter \#2 series of the (a) $\mathrm{Rh} / \gamma-\mathrm{Al}_{2} \mathrm{O}_{3}$, (b) $\mathrm{Rh} / \mathrm{ACZ}$ and (c) Rh/CZ samples shown in Figure 4. The resulting mean particle sizes are summarized in Table 2, while the influence of sintering time/temperature and support oxygen storage capacity on $\mathrm{Rh}$ particle growth or redispersion defined by the equation

$$
\% \text { Rh particle growth }=100 \cdot\left(\mathrm{PS}-\mathrm{PS}^{\mathrm{o}}\right) / \mathrm{PS}^{\mathrm{o}}
$$


are shown in Figures 5 and 6, respectively, where PS denotes mean Rh particle size and the superscript "0" refers to fresh unsintered samples.

The particle sizes (Table 2) measured by TEM (a local technique) and $\mathrm{H}_{2}$-chemisorption (a surface average technique) are in close agreement. Note, however, that the TEM particle size is a number average (counted once per particle) that includes only particles above the instrumental detection limit. $\mathrm{H}_{2}$-chemisorption is a highly sensitive technique that assays all different sizes of $\mathrm{Rh}$ clusters on the catalyst surface (though possibly vulnerable to some error from metal-support interaction effects and spillover of hydrogen from the metal to or from the support). $\mathrm{H}_{2}$-chemisorption was, therefore, used as the preferred method for monitoring particle growth and redispersion.

Table 2. Sintering characteristics of the fresh Rh catalysts exposed to oxidative thermal aging. (Sinter \#1: 2 h@ $750{ }^{\circ} \mathrm{C}$; Sinter \#2: $\left.2 \mathrm{~h} @ 750^{\circ} \mathrm{C}+2 \mathrm{~h} @ 850{ }^{\circ} \mathrm{C}\right)$.

\begin{tabular}{ccccccc}
\hline \multirow{2}{*}{ Catalysts } & \multicolumn{2}{c}{ Fresh } & \multicolumn{2}{c}{ Sinter \#1 } & \multicolumn{2}{c}{ Sinter \#2 } \\
\cline { 2 - 7 } & $\mathbf{H}_{\mathbf{2}}$-Chem & HRTEM & $\mathbf{H}_{\mathbf{2}}$-Chem & HRTEM & H $_{\mathbf{2}}$-Chem & HRTEM \\
\hline $\mathrm{Rh} / \gamma-\mathrm{Al}_{\mathbf{2}} \mathbf{O}_{\mathbf{3}}$ & $\mathbf{1 . 2}$ & $1.3 \pm 0.4$ & $\mathbf{1 . 6}$ & $1.6 \pm 0.3$ & $\mathbf{2 . 6}$ & $1.6 \pm 0.3$ \\
\hline $\mathrm{Rh} / \mathrm{ACZ}$ & $\mathbf{1 . 8}$ & $1.5 \pm 0.5$ & $\mathbf{1 . 4}$ & $2.0 \pm 0.8$ & $\mathbf{1 . 7}$ & $1.5 \pm 0.4$ \\
\hline $\mathrm{Rh} / \mathrm{CZ}$ & $\mathbf{5 . 0}$ & $5.1 \pm 1.7$ & $\mathbf{2 . 1}$ & $2.5 \pm 0.7$ & $\mathbf{2 . 2}$ & $2.0 \pm 0.7$ \\
\hline
\end{tabular}

Nanoparticles on $\gamma-\mathrm{Al}_{2} \mathrm{O}_{3}$ exhibited an about $33 \%$ growth after procedure Sinter $\# 1$ and significantly higher growth, $117 \%$, after additional sintering according to Sinter \#2 (Figure 5, Table 2 and TEM images Figure $4 \mathrm{~A}(\mathrm{a}) \rightarrow 4 \mathrm{~B}(\mathrm{a}) \rightarrow 4 \mathrm{C}(\mathrm{a})$ ). In contrast, nanoparticles on $\mathrm{ACZ}$, and especially on $\mathrm{CZ}$, underwent redispersion, which is much more pronounced in the latter case: An initial $\sim 22 \%$ redispersion on $\mathrm{Rh} / \mathrm{ACZ}$ after $2 \mathrm{~h}$ of sintering at $750^{\circ} \mathrm{C}$ (Sinter \#1) was followed by particle growth after two additional hours sintering at $850^{\circ} \mathrm{C}$ (Sinter \#2), finally leading to only marginal redispersion of $\sim 6 \%$ (Figure 5 , Table 2 and TEM images Figure $4 \mathrm{~A}(\mathrm{~b}) \rightarrow 4 \mathrm{~B}(\mathrm{~b}) \rightarrow 4 \mathrm{C}(\mathrm{b})$ ). For $\mathrm{Rh} / \mathrm{CZ}$ however, an initial extended redispersion of $\sim 58 \%$ occurred during Sinter \#1 and remained almost unaffected after Sinter \#2 (Figure 5, Table 2 and TEM images Figure $4 \mathrm{~A}(\mathrm{c}) \rightarrow 4 \mathrm{~B}(\mathrm{c}) \rightarrow 4 \mathrm{C}(\mathrm{c})$ ).

Clearly, the nature of the support strongly influences the oxidative sintering behavior of $\mathrm{Rh}$ nanoparticles: Supports without or negligible amounts of labile lattice oxygen (i.e., $\gamma-\mathrm{Al}_{2} \mathrm{O}_{3}$ with OSC $\sim 0$ ) do not prevent particle growth of $\mathrm{Rh}$, as found recently for Ir nanoparticles supported on $\gamma-\mathrm{Al}_{2} \mathrm{O}_{3}[8,27,28]$. In contrast, supports with high oxygen ion lability (i.e., $\mathrm{ACZ}$ and CZ with OSC of 101 and $557 \mu \mathrm{mol} \mathrm{O} \mathrm{g}^{-1}$, respectively) not only prevent sintering as also found for $\operatorname{Ir}[8,27,28]$, but actually promote Rh redispersion: The higher the OSC of the support, the greater the resulting redispersion, as shown in Figure 6. 


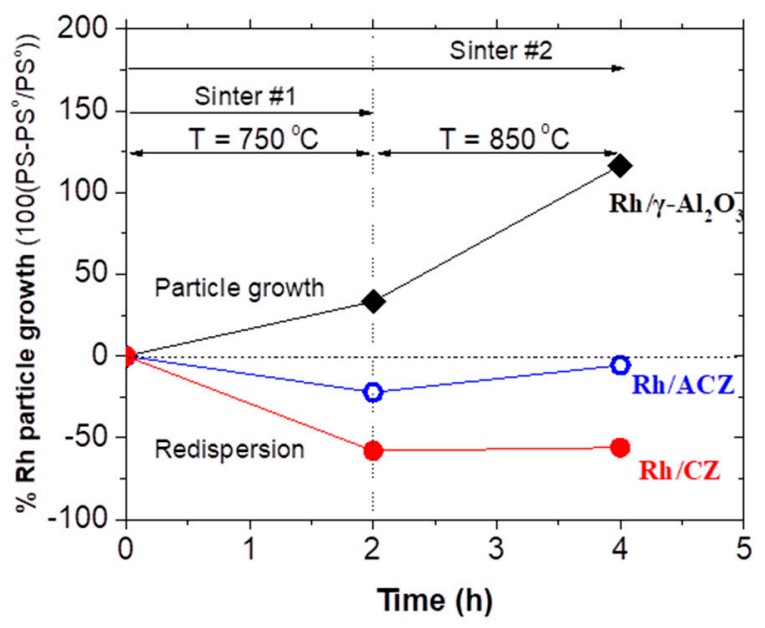

Figure 5. \% Rh particle growth (+) or redispersion (-) of Rh nanoparticles supported on $\gamma-\mathrm{Al}_{2} \mathrm{O}_{3}, \mathrm{ACZ}$ and $\mathrm{CZ}$ versus sintering time and temperature under oxidizing environment $\left(20 \% \mathrm{O}_{2} / \mathrm{He}\right)$. (Results are based on $\mathrm{H}_{2}$-chemisorption data).

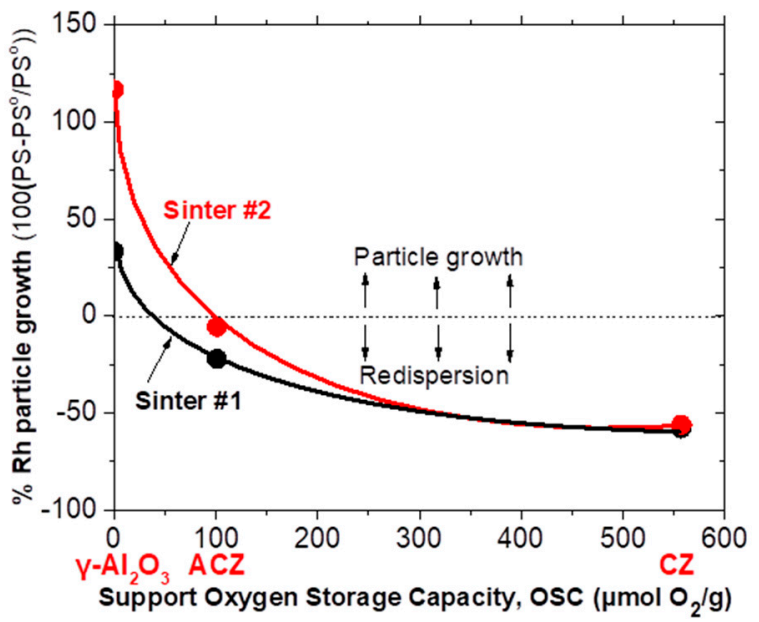

Figure 6. \% Rh particle growth (+) or redispersion (-) versus oxygen storage capacity of the support for Sinter \#1 and Sinter \#2 conditions. (Results are based on $\mathrm{H}_{2}$-chemisorption data).

\subsection{Mechanistic Implications of Sinter-Resistant and Redispersion Phenomena}

Oxidative redispersion of supported platinum group metals is well known, as recently reviewed by Morgan et al. [30]. In the case of reducible supports, such as ACZ and CZ, it is most likely mediated by metal-support interaction involving atomic trapping [11-13] at support sites of atomic species detached from nanoparticles (the initiating step in the OR mechanism of sintering [18-20]). As shown in the present work, redispersion depends strongly on the reducibility of the support, i.e., its labile lattice oxygen content, or, equivalently, its oxygen storage capacity (Figures 5 and 6); the effect is very pronounced on $\mathrm{CZ}$, less so on $\mathrm{ACZ}$ and absent in the case of $\gamma-\mathrm{Al}_{2} \mathrm{O}_{3}$. In the latter case, extensive particle growth occurred, rather than redispersion. It is therefore reasonable to conclude that surface oxygen defects in the support, so-called oxygen vacancies $\left(\mathrm{V}_{\ddot{\mathrm{O}}}\right.$ in Kröger-Vink defect notation for point defects in crystals) are the active centers for atom trapping.

We recently developed a plausible model which explained the resistance to oxidative thermal sintering of Ir nanoparticles dispersed on oxide supports with high oxygen ion lability $[8,27,28]$. This involved the key role of the effective double layer $\left[\mathrm{O}^{\delta-}, \delta^{+}\right]$account of metal-support interactions $[3,9$, $10,46]$, whereby thermally driven $\mathrm{O}^{2-}$ back-spillover from supports with substantial labile oxygen onto catalyst nanoparticles affects not only their intrinsic surface activity [3-10,46], but also their sintering behavior (Figure 7), as we demonstrated for the first time in References $[8,27,28]$. We argued that the 
$\left[\mathrm{O}^{\delta-}, \delta^{+}\right]$double layer endows catalyst particles with a negative charge at their gas-exposed surfaces, leading to interparticle repulsion at short range, thus preventing particle-particle encounters followed by coalescence (i.e., $\mathrm{PMC}$ ): The higher the lability of $\mathrm{O}^{2-}$ in the support, the lower the vulnerability of the nanoparticles to sintering in an oxidative environment $[8,27]$. The model also implied simultaneous occurrence of atomic trapping as a contributing factor in the sinter-resistant mechanism: Labile support lattice oxygen creates surface oxygen vacancies $\left(\mathrm{V}_{\ddot{\mathrm{O}}}\right)$ that act as traps for very small (atomic) metal particles, thus inhibiting their diffusion and agglomeration [8]. At the same time, the $\mathrm{O}^{\delta-}$ modified surface barrier present on large catalyst particles increases the activation energies for detachment and reattachment of metal entities whose transport would otherwise lead to continuous growth of large particles at the expense of smaller particles according to the OR model of sintering.

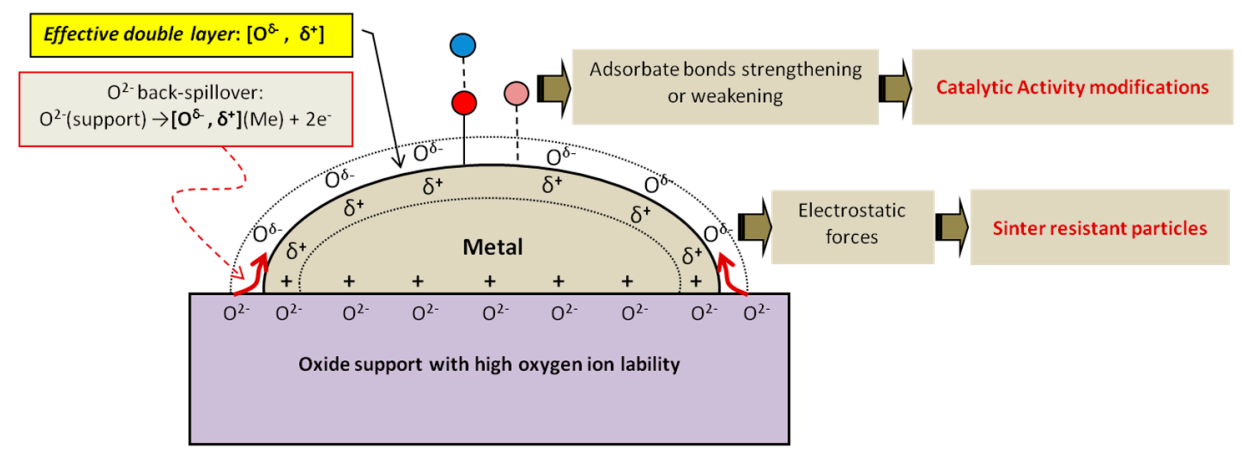

Figure 7. The mechanism of formation of the effective double layer $\left[\mathrm{O}^{\delta-}, \delta^{+}\right]$and its roles in surface catalytic phenomena and inhibition of metal sintering.

These effects on metal transport would be negligible for low-lability supports (e.g., $\mathrm{Al}_{2} \mathrm{O}_{3}$ ), which therefore cannot prevent particle agglomeration by either PMC or OR mechanisms. It is worth noting that pure $\mathrm{CeO}_{2}$ has a relatively low concentration of lattice defects in comparison to $\mathrm{Gd}_{2} \mathrm{O}_{3}$ or $\mathrm{ZrO}_{2}$-doped $\mathrm{CeO}_{2}$. Therefore, the optimal supports for providing sinter resistance should be those with highest $\mathrm{O}^{2-}$ ion mobility, such as $\mathrm{CeO}_{2}$ modified with cations such as gadolinium, zirconium and others that act to enhance ceria lattice defects, increasing $\mathrm{O}^{2-}$ vacancies and consequently $\mathrm{O}^{2-}$ mobility $[5,47,48]$.

A summary of the factors that inhibit sintering according to effective double-layer approach is depicted schematically Figure 8. Three mechanistic paths are associated with particle growth and our model includes several factors that control their occurrence and strength. Path I concerns large particle migration and coalescence (PMC) which, in our model, can be strongly inhibited by electrostatic interparticle repulsion due to the presence of the effective double layer. Path II ( $a$ and $b$ ) concerns the OR sequence, i.e., atom detachment (IIa) and reattachment (IIb), both of which are inhibited by the increased activation energies arising from the $\mathrm{O}^{\delta-}$-modified metal particle surfaces. Path III concerns the diffusion of detached atomic species from smaller particles towards larger ones, which is strongly inhibited by atom trapping at $\mathrm{V}_{\ddot{\mathrm{O}}}$ centers.

According to this view, the behavior of Rh particles towards sintering shown in Figures 5 and 6 may be rationalized. The absence of an effective double layer $\left(\mathrm{Rh} / \mathrm{Al}_{2} \mathrm{O}_{3}\right)$ leads to severe particle growth, up to $\sim 120 \%$ as a function of sintering time and temperature (Figure 5); none of the possible antisintering factors are available. On the other hand, the presence of an effective double layer and its effects on metal transport can lead to either moderate particle growth, sinter prevention or even redispersion, depending on the strength of the phenomena. Thus, for $\mathrm{Rh} / \mathrm{ACZ}$, characterized by moderate oxygen ion lability, an initial slight redispersion after $2 \mathrm{~h}$ under sintering conditions was almost quenched after $4 \mathrm{~h}$. Evidently, the moderately intense effective double layer could suppress PMC by interparticle repulsion forces, although path IIa, i.e., atom detachment via Ostwald ripening, still seems to have been operating. Diffusing detached atoms on the mixed alumina-CZ surface initially had a finite possibility of encountering trapping centers on the $\mathrm{CZ}$ compartment. Otherwise, they were 
recaptured by large particles, resulting in moderate redispersion (Figure 5). Under further sintering, the population of Rh atom trapping centers was progressively reduced, eventually reversing the net effect as observed (Figure 5). We cannot exclude the possibility that some detached atoms underwent diffusion on the alumina component of the ACZ support. Nevertheless, the overall sintering propensity should be less than that of pure $\mathrm{Rh} / \mathrm{Al}_{2} \mathrm{O}_{3}$, accounting for the very different sintering behavior of $\mathrm{Rh} / \mathrm{Al}_{2} \mathrm{O}_{3}$ and $\mathrm{Rh} / \mathrm{ACZ}$; the sintering characteristics of $\mathrm{Rh} / \mathrm{ACZ}$ are closer to those of $\mathrm{Rh} / \mathrm{CZ}$ than $\mathrm{Rh} / \mathrm{Al}_{2} \mathrm{O}_{3}$ (Figures 5 and 6). Finally, with $\mathrm{Rh} / \mathrm{CZ}$, the expected dense effective double layer on $\mathrm{Rh}$ particles strongly suppressed PMC. At the same time, the concomitant high population of support trapping centers acted to efficiently trap detached atoms strongly inhibiting the occurrence of path IIb. The net result was pronounced Rh redispersion, even after prolonged sintering (Figures 5 and 6).

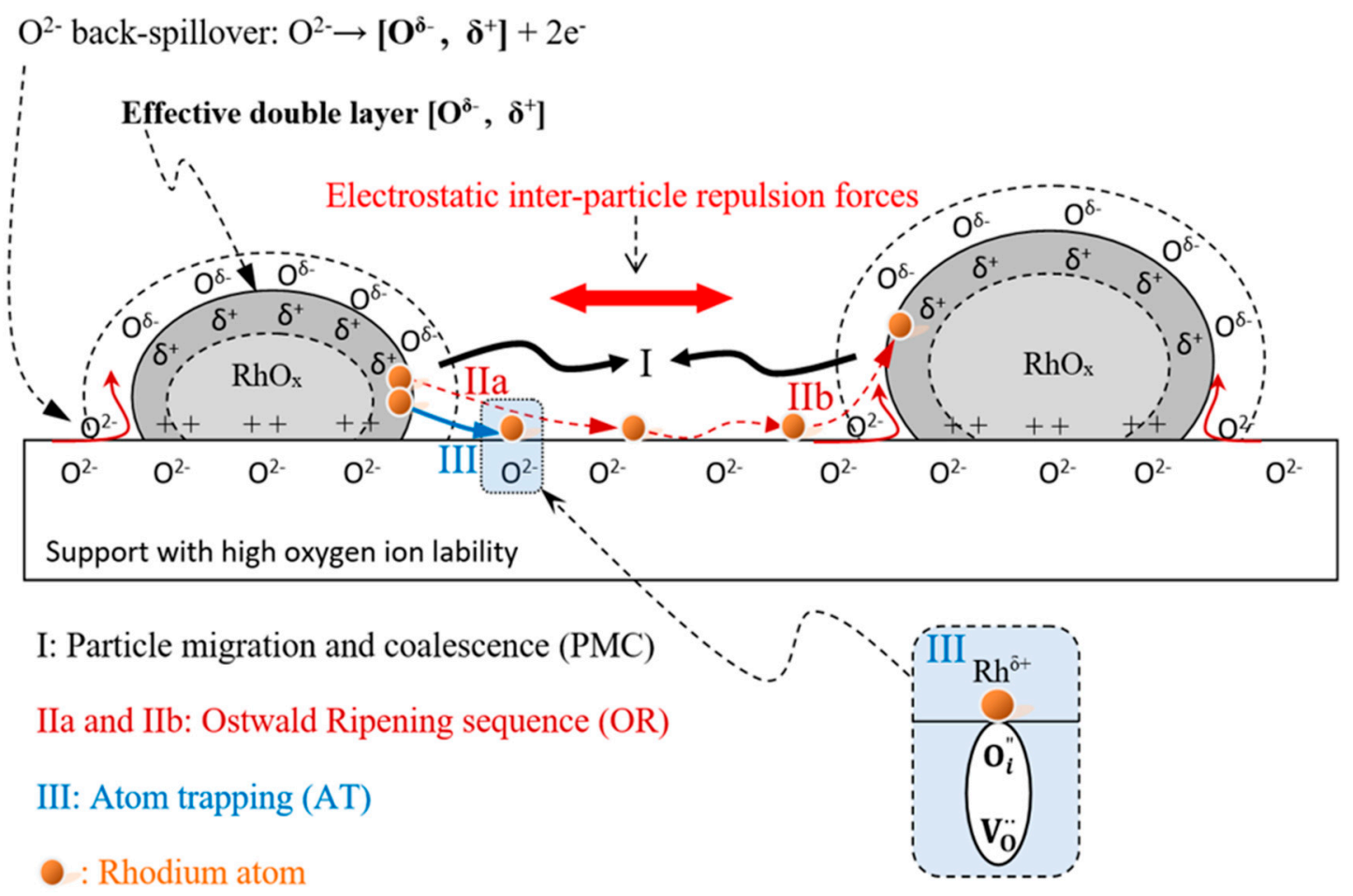

Figure 8. Model for sintering resistance against PMC or OR and redispersion induced by the simultaneous action of interparticle repulsion forces arising from effective double layer and atom trapping at oxygen ion vacancies. $\left(\mathrm{O}_{i}^{\prime \prime}\right.$ is the Krönger-Vink notation for interstitial (labile) $\mathrm{O}^{2-}$; their concentration is determined by the equilibrium $\mathrm{O}_{\mathrm{O}} \leftrightarrow \mathrm{V}_{\ddot{\mathrm{O}}}+\mathrm{O}_{i}^{\prime \prime}$ between lattice oxygen and oxygen ion vacancies [43]).

\section{Experimental}

\subsection{Preparation and Aging of Catalysts}

$\mathrm{Rh}$ nanoparticles were dispersed by wet impregnation on $\gamma-\mathrm{Al}_{2} \mathrm{O}_{3}, \mathrm{ACZ}\left(80 \mathrm{wt} \% \mathrm{Al}_{2} \mathrm{O}_{3}-20 \mathrm{wt}\right.$ $\left.\% \mathrm{Ce}_{0.5} \mathrm{Zr}_{0.5} \mathrm{O}_{2-\delta}\right)$ and $\mathrm{CZ}\left(\mathrm{Ce}_{0.5} \mathrm{Zr}_{0.5} \mathrm{O}_{2-\delta}\right)$ supports, with a $1.0 \mathrm{wt} \% \mathrm{Rh}$ nominal loading. $\gamma-\mathrm{Al}_{2} \mathrm{O}_{3}$ was obtained from Engelhard (Engelhard de Meern B.V., The Netherlands) and ground to a powder. Powders of $\mathrm{ACZ}$ and $\mathrm{CZ}$ were prepared by coprecipitation, of the corresponding precursor salts $\mathrm{Al}\left(\mathrm{NO}_{3}\right)_{3} \cdot 9 \mathrm{H}_{2} \mathrm{O}, \mathrm{Zr}\left(\mathrm{NO}_{3}\right)_{2} \cdot \mathrm{H}_{2} \mathrm{O}$ and $\mathrm{Ce}\left(\mathrm{NO}_{3}\right)_{3} \cdot 6 \mathrm{H}_{2} \mathrm{O}$ supplied by Alfa Aesar (Haverhill, MA, USA), followed by calcination at $800^{\circ} \mathrm{C}$ for $1 \mathrm{~h}$, as described in detail elsewhere [7].

Rhodium (III) nitrate solution ( $10 \% \mathrm{w} / \mathrm{v} \mathrm{Rh}$ in $20-25 \mathrm{wt} \% \mathrm{HNO}_{3}$ ) purchased from Acros Organics was used as the metal precursor after dilution in water in order to produce a $2 \mathrm{mg} \mathrm{Rh} / \mathrm{mL}$ concentrated solution of $\mathrm{Rh}\left(\mathrm{NO}_{3}\right)_{3}$. An appropriate amount of each support was impregnated with this solution under continuous stirring at $75{ }^{\circ} \mathrm{C}$ to yield supported catalysts with $1.0 \mathrm{wt} \% \mathrm{Rh}$ nominal loading. 
After water evaporation, the suspension was dried at $110^{\circ} \mathrm{C}$ for $12 \mathrm{~h}$ and then calcined in air at $450{ }^{\circ} \mathrm{C}$ for $1 \mathrm{~h}$ to decompose the nitrate precursor. The resulting materials were reduced at $400{ }^{\circ} \mathrm{C}$ under $50 \%$ $\mathrm{H}_{2} / \mathrm{He}$ flow for $2 \mathrm{~h}$ followed by heating $\left(20^{\circ} \mathrm{C} / \mathrm{min}\right)$ under $1 \% \mathrm{H}_{2} / \mathrm{He}$ flow to $800^{\circ} \mathrm{C}$, maintained for $1 \mathrm{~h}$. The as-prepared $\mathrm{Rh} / \gamma-\mathrm{Al}_{2} \mathrm{O}_{3}, \mathrm{Rh} / \mathrm{ACZ}$ and $\mathrm{Rh} / \mathrm{CZ}$ catalysts are hereafter denoted as "fresh" (Table 1 ).

Sintering behavior was investigated by means of two aging protocols: (i) Heating in $10 \mathrm{NmL} \cdot \mathrm{min}^{-1}$ $20 \% \mathrm{O}_{2} / \mathrm{He}$ flow at $750{ }^{\circ} \mathrm{C}$ for $2 \mathrm{~h}$, and (ii) heating in $10 \mathrm{NmL} \cdot \mathrm{min}^{-1} 20 \% \mathrm{O}_{2} / \mathrm{He}$ flow at $750{ }^{\circ} \mathrm{C}$ for $2 \mathrm{~h}$ followed by further heating at $850{ }^{\circ} \mathrm{C}$ for $2 \mathrm{~h}$, hereafter denoted as Sinter \#1 and Sinter \#2 samples, respectively. In accord with the literature, no rhodium weight loss is expected at these temperatures and times [49-51].

\subsection{Characterization Methods}

Textural, structural and other physicochemical characterizations of the catalysts were performed by a variety of techniques as follows:

Inductively Coupled Plasma-Optical Emission Spectroscopy (ICP-OES) Measurements: Total Rh contents were obtained by means of ICP-OES using a Thermo Scientific iCAP 7400 duo instrument (Waltham, MA, USA). Details of the method and sample pretreatment before the ICP-OES measurements can be found in our previous report [43].

BET Measurements: Total surface areas $\left(\mathrm{S}_{\mathrm{BET}}\right)$, average pore volume and mean pore size diameters were determined according to the Brunauer-Emmett-Teller (BET) and Barret-Joyner-Halenda (BJH) methods from $\mathrm{N}_{2}$ adsorption-desorption isotherms obtained with a Quantachrome Nova 2200e instrument (Boynton Beach, FL, USA) at $-196{ }^{\circ} \mathrm{C}$. The total pore volume calculation was based on the nitrogen volume obtained at the highest relative pressure. Prior to measurements, the samples were degassed at $350{ }^{\circ} \mathrm{C}$ for $12 \mathrm{~h}$ under vacuum.

Isothermal Hydrogen Chemisorption ( $\mathrm{H}_{2}$-Chem.): Determination of the number of $\mathrm{Rh}$ surface sites, (Rh dispersion) and the associated crystallite sizes were achieved by isothermal (at $0{ }^{\circ} \mathrm{C}$ ) hydrogen chemisorption measurements carried out on a Quantachrome ChemBet Pulsar TPR/TPD chemisorption analyzer (Boynton Beach, Florida) equipped with an Omnistar/Pfeiffer Vacuum mass spectrometer. To this end, $\sim 150 \mathrm{mg}$ of catalyst was loaded into a quartz U-tube connected to the analyzer and pretreated as follows before the measurement: Reduction at $550{ }^{\circ} \mathrm{C}$ for $1 \mathrm{~h}$ with a flux of $5 \% \mathrm{H}_{2}$ in $\mathrm{He}(15 \mathrm{NmL} / \mathrm{min})$, gas phase purging at the same temperature for $0.5 \mathrm{~h}$ by $\mathrm{N}_{2}$ flux $(15 \mathrm{Nm} / \mathrm{min})$ and finally cooling $0{ }^{\circ} \mathrm{C}$ (ice/water bath) under $\mathrm{N}_{2}$ flow. Pulses of pure hydrogen $(280 \mu \mathrm{L})$ were then injected until saturation, thus providing the total uptake of chemisorbed hydrogen. These values were used to estimate the number of active surface sites, and hence Rh dispersion and mean crystallite size. The low temperature used for these measurements avoided hydrogen spillover in the case of $\mathrm{CeO}_{2}$-containing supports.

Hydrogen Temperature Programmed Reduction Measurements: $\mathrm{H}_{2}$-TPR measurements were carried out in the temperature interval $30-850{ }^{\circ} \mathrm{C}$ using the same instrumentation as employed for $\mathrm{H}_{2}$-chemisorption experiments. To this end, $150 \mathrm{mg}$ of catalyst was loaded into a quartz U-tube connected to the TPR apparatus and preoxidized in situ with $20 \% \mathrm{O}_{2} / \mathrm{He}$ at $750{ }^{\circ} \mathrm{C}$ for $0.5 \mathrm{~h}$, cooled to room temperature under the same atmosphere, then purged under He flow for $0.5 \mathrm{~h}$. After this pretreatment, a flow of 15 $\mathrm{NmL} \min ^{-1}$ of $1 \% \mathrm{v} / \mathrm{v} \mathrm{H}_{2}$ in He was continuously passed through the sample and a linear temperature ramp from $\sim 30^{\circ} \mathrm{C}$ up to $850{ }^{\circ} \mathrm{C}$ was applied at $10^{\circ} \mathrm{C} \mathrm{min}-1$ and the $\mathrm{H}_{2}$ content of the effluent gas was measured by MS ( $\mathrm{H}_{2}$-TPR spectra). The integrated peak areas were used to calculate the total amount of $\mathrm{H}_{2}$ consumed (in $\mu \mathrm{mol} \mathrm{H}_{2} \mathrm{~g}^{-1}$ ) by labile lattice oxygen; half of this quantity represents the total oxygen storage capacity, OSC, in $\mu \mathrm{mol} \mathrm{O}_{2} \mathrm{~g}^{-1}[52,53]$.

TEM Measurements: High-resolution TEM images obtained with an aberration corrected JEOL 2100-F microscope (Tokyo, Japan) operated at $200 \mathrm{kV}$. Samples were gently ground in high-purity methanol using an agate pestle and mortar prior to TEM observations. The resulting samples were deposited on 300-mesh-carbon-supported copper grids and dried under ambient conditions. ImageJ 1.41 software was used for Image analysis. In order to enable the comparison between Rh particle 
sizes obtained by $\mathrm{H}_{2}$-chemisoprtion and by TEM, the latter were performed with samples that were preconditioned under the same reducing conditions as those used for the $\mathrm{H}_{2}$-chemisoprtion experiments.

Powder X-ray Diffraction Measurements: PXRD characterization of the fresh catalysts was performed with a Bruker D8 Advance Diffractometer (Billerica, MA, USA) with a LynxEye high-speed strip detector using $\mathrm{Cu} \mathrm{K} \mathrm{K}_{\alpha 1}(\lambda=0.1542 \mathrm{~nm})$ radiation.

\section{Conclusions}

Rh nanoparticles dispersed on a variety of oxide supports exhibit markedly different thermal sintering characteristics under oxidative environments, which correlate with the oxygen ion lability of the support.

- $\gamma-\mathrm{Al}_{2} \mathrm{O}_{3}$ provided little or no resistance to sintering, leading to $\sim 50 \% \mathrm{Rh}$ particle growth at $750{ }^{\circ} \mathrm{C}$ after $2 \mathrm{~h}$ and $\sim 150 \%$ at $850{ }^{\circ} \mathrm{C}$ after two additional hours.

- High resistance to sintering and even redispersion occurred on $\mathrm{ACZ}$ and $\mathrm{CZ}$, characterized respectively by moderate and high values of labile lattice oxygen capacity $(\sim 101$ and $557 \mu \mathrm{mol}$ $\mathrm{O}_{2} \mathrm{~g}^{-1}$, respectively); the higher the OSC of the support, the greater the extent of particle redispersion-which increased with increasing sintering temperature.

This resistance to sintering and the previously unreported actual redispersion of Rh particles can be rationalized by taking into account the synergistic action of two phenomena: (i) The presence of a spontaneously formed $\left[\mathrm{O}^{\delta-}, \delta^{+}\right]$double layer on the metal particles resulting from thermally driven oxygen back-spillover from high OSC supports. This effect quenches large particle migration and coalescence (PMC) due to the resulting interparticle electrostatic repulsion and (ii) the trapping of Rh atoms detached from large Rh crystallites by surface oxygen vacancies in the support material, thus suppressing diffusion of rhodium species on the support and their subsequent attachment to larger particles; the higher the population of surface oxygen vacancies on the support the greater the redispersion of $\mathrm{Rh}$, which increased with temperature.

The observed behavior is fully consistent with the proposed model.

In light of these findings a new methodology for in situ on-stream controlled redispersion of metal catalysts may be devised, with potentially major implications for industrial heterogeneous catalysis.

Supplementary Materials: The following are available online at http://www.mdpi.com/2073-4344/9/6/541/s1. Table S1: $\mathrm{H}_{2}$-uptake values obtained by the isothermal $\mathrm{H}_{2}$-chemisorption experiments and corresponding $\mathrm{Rh}$ dispersion values, D (\%); Equations used for the calculation of dispersion, active metal surface area and particle size values.

Author Contributions: G.G., G.B., contributed to materials synthesis, characterization and analysis of the results; A.O., C.M.A.P. and G.K. contributed to materials characterization and analysis of the results; G.K. and R.M.L. contributed to results interpretation and paper writing; I.V.Y. contributed to the conceptualization, methodology, results interpretation and visualization, writing the original draft and funding acquisition; All authors contributed to review and editing, discussion, read and approved the final version of the manuscript.

Funding: This research was co-financed by the European Union and Greek national funds through the Operational Program Competitiveness, Entrepreneurship and Innovation, under the call RESEARCH-CREATE-INNOVATE (project code: T1E $\Delta \mathrm{K}-00782$ ).

Acknowledgments: The authors acknowledge financial support by the European Union and Greek national funds through the Operational Program "Competitiveness, Entrepreneurship and Innovation", under the call "RESEARCH-CREATE-INNOVATE" (project code: T1EAK-00782).

Conflicts of Interest: The authors declare no conflicts of interest.

\section{References}

1. Yang, X.-F.; Wang, A.; Qiao, B.; Li, J.; Liu, J.; Zhang, T. Single-atom catalysts: A new frontier in heterogeneous catalysis. Acc. Chem. Res. 2013, 46, 1740-1748. [CrossRef] [PubMed]

2. Flytzani-Stephanopoulos, M.; Gates, B.C. Atomically dispersed supported metal catalysts. Ann. Rev. Chem. Biomol. Eng. 2012, 3, 545-574. [CrossRef] 
3. Pliangos, A.; Yentekakis, I.V.; Papadakis, V.G.; Vayenas, C.G.; Verykios, X.E. Support-induced promotional effects on the activity of automotive exhaust catalysts: 1 . The case of oxidation of light hydrocarbons $\left(\mathrm{C}_{2} \mathrm{H}_{4}\right)$. Appl. Catal. B Environ. 1997, 14, 161-173. [CrossRef]

4. Papadakis, V.G.; Pliangos, C.A.; Yentekakis, I.V.; Verykios, X.E.; Vayenas, C.G. Development of high performance, Pd-based, three way catalysts. Catal. Today 1996, 29, 71-75. [CrossRef]

5. Yentekakis, I.V.; Pliangos, C.A.; Papadakis, V.G.; Verykios, X.E.; Vayenas, C.G. Support and NEMCA induced promotional effects on the activity of automotive exhaust catalysts. Stud. Surf. Sci. Catal. 1995, 96, 375-385. [CrossRef]

6. Konsolakis, M.; Drosou, C.; Yentekakis, I.V. Support mediated promotional effects of rare earth oxides $\left(\mathrm{CeO}_{2}\right.$ and $\mathrm{La}_{2} \mathrm{O}_{3}$ ) on $\mathrm{N}_{2} \mathrm{O}$ decomposition and $\mathrm{N}_{2} \mathrm{O}$ reduction by $\mathrm{CO}$ and $\mathrm{C}_{3} \mathrm{H}_{6}$ over $\mathrm{Pt} / \mathrm{Al}_{2} \mathrm{O}_{3}$ structured catalysts. Appl. Catal. B 2012, 123-124, 405-413. [CrossRef]

7. Papavasiliou, A.; Tsetsekou, A.; Matsuka, V.; Konsolakis, M.; Yentekakis, I.V. An investigation of the role of $\mathrm{Zr}$ and La dopants into $\mathrm{Ce}_{1-\mathrm{x}-\mathrm{y}} \mathrm{Zr}_{\mathrm{x}} \mathrm{La}_{\mathrm{y}} \mathrm{O}_{\delta}$ enriched $\gamma-\mathrm{Al}_{2} \mathrm{O}_{3}$ TWC washcoats. Appl. Catal. A 2010, 382, $73-84$. [CrossRef]

8. Yentekakis, I.V.; Goula, G.; Kampouri, S.; Betsi-Argyropoulou, I.; Panagiotopoulou, P.; Taylor, M.J.; Kyriakou, G.; Lambert, R.M. Ir-catalyzed Nitrous oxide $\left(\mathrm{N}_{2} \mathrm{O}\right)$ decomposition: Effect of the Ir particle size and metal-support interactions. Catal. Lett. 2018, 148, 341-347. [CrossRef]

9. Nicole, J.; Tsiplakides, D.; Pliangos, C.; Verykios, X.E.; Comninellis, C.; Vayenas, C.G. Electrochemical promotion and metal-support interactions. J. Catal. 2001, 204, 23-34. [CrossRef]

10. Vernoux, P.; Lizarraga, L.; Tsampas, M.N.; Sapountzi, F.M.; De Lucas-Consuegra, A.; Valverde, J.-L.; Souentie, S.; Vayenas, C.G.; Tsiplakides, D.; Balomenou, S.; et al. Ionically Conducting Ceramics as Active Catalyst Supports. Chem. Rev. 2013, 113, 8192-8260. [CrossRef]

11. Datye, A.; Wang, Y. Atom trapping: A novel approach to generate thermally stable and regenerable single-atom catalysts. Natl. Sci. Rev. 2018, 5, 630-632. [CrossRef]

12. Qiao, B.; Wang, A.; Yang, X.; Allard, L.F.; Jiang, Z.; Cui, Y.; Liu, J.; Li, J.; Zhang, T. Single-atom catalysis of CO oxidation using $\mathrm{Pt}_{1} / \mathrm{FeO} x$. Nat. Chem. 2011, 3, 634-641. [CrossRef] [PubMed]

13. Jones, J.; Xiong, H.; DeLaRiva, A.T.; Peterson, E.J.; Pham, H.; Challa, S.R.; Qi, G.; Oh, S.; Wiebenga, M.H.; Hernandez, X.I.P.; et al. Thermally stable single-atom platinum-on-ceria catalysts via atom trapping. Science 2016, 353, 150-154. [CrossRef] [PubMed]

14. Grillo, F.; Van Bui, H.; Moulijn, J.A.; Kreutzer, M.T.; van Ommen, R. Understanding and controlling the aggregative growth of platinum nanoparticles in atomic layer deposition: An avenue to size selection. J. Phys. Chem. Lett. 2017, 8, 975-983. [CrossRef] [PubMed]

15. Grillo, F.; Van Bui, H.; La Zara, D.; Aarnink, A.I.; Kovalgin, A.Y.; Kooyman, P.; Kreutzer, M.T.; van Ommen, R. From single atoms to nanoparticles: Autocatalysis and metal aggregation in atomic layer deposition of $\mathrm{Pt}$ on $\mathrm{TiO}_{2}$ nanopowder. Small 2018, 14, 1800765. [CrossRef] [PubMed]

16. Moulijn, J.A.; van Diepen, A.E.; Kapteijn, F. Catalyst deactivation: Is it predictable? What to do? Appl. Catal. A 2001, 212, 3-16. [CrossRef]

17. Hu, S.; Li, W.-X. Influence of particle size distribution on lifetime and thermal stability of Ostwald ripening of supported particles. ChemCatChem 2018, 10, 1-9. [CrossRef]

18. Dai, Y.; Lu, P.; Cao, Z.; Campbell, C.T.; Xia, Y. The physical chemistry and materials science behind sinter-resistant catalysts. Chem. Soc. Rev. 2018, 47, 4314-4331. [CrossRef] [PubMed]

19. Goodman, E.D.; Schwalbe, J.A.; Cargnello, M. Mechanistic understanding and rational design of sinter-resistant heterogeneous catalysts. ACS Catal. 2017, 7, 7156-7173. [CrossRef]

20. Hansen, T.W.; DeLaRiva, A.T.; Challa, S.R.; Datye, A.K. Sintering of Catalytic Nanoparticles: Particle Migration or Ostwald Ripening? Acc. Chem. Res. 2013, 46, 1720-1730. [CrossRef] [PubMed]

21. Argyle, M.D.; Bartholomew, C.H. Heterogeneous Catalyst Deactivation and Regeneration: A Review. Catalysts 2015, 5, 145-269. [CrossRef]

22. Simonsen, S.B.; Chorkendorff, I.; Dahl, S.; Skoglundh, M.; Sehested, J.; Helveg, S. Direct observations of oxygen-induced platinum nanoparticle ripening studied by in situ TEM. J. Am. Chem. Soc. 2010, 132, 7968-7975. [CrossRef] [PubMed]

23. DeLaRiva, A.T.; Hansen, T.W.; Challa, S.R.; Datye, A.K. In situ Transmission Electron Microscopy of catalyst sintering. J. Catal. 2013, 308, 291-305. [CrossRef] 
24. Fiedorow, R.M.J.; Chahar, B.S.; Wanke, S.E. The sintering of supported metal catalysts. II. Comparison of sintering rates of supported Pt, Ir, and Rh Catalysts in hydrogen and oxygen. J. Catal. 1978, 51, 193-202. [CrossRef]

25. Nagai, Y.; Hirabayashi, T.; Dohmae, K.; Takagi, N.; Minami, T.; Shinjoh, H.; Matsumoto, S. Sintering inhibition mechanism of platinum supported on ceria-based oxide and Pt-oxide-support interaction. J. Catal. 2006, 242, 103-109. [CrossRef]

26. Hatanaka, M.; Takahashi, N.; Tanabe, T.; Nagai, Y.; Dohmae, K.; Aoki, Y.; Yoshida, T.; Shinjoh, H. Ideal Pt loading for a Pt/ $\mathrm{CeO}_{2}$-based catalyst stabilized by Pt-O-Ce bond. Appl. Catal. B 2010, 99, 336-342. [CrossRef]

27. Yentekakis, I.V.; Goula, G.; Panagiotopoulou, P.; Kampouri, S.; Taylor, M.J.; Kyriakou, G.; Lambert, R.M. Stabilization of catalyst particles against sintering on oxide supports with high oxygen ion lability exemplified by Ir-catalysed decomposition of $\mathrm{N}_{2} \mathrm{O}$. Appl. Catal. B 2016, 192, 357-364. [CrossRef]

28. Yentekakis, I.V.; Goula, G.; Panagiotopoulou, P.; Katsoni, A.; Diamadopoulos, E.; Mantzavinos, D.; Delimitis, A. Dry reforming of methane: Catalytic performance and stability of Ir catalysts supported on $\gamma-\mathrm{Al}_{2} \mathrm{O}_{3}$, $\mathrm{Zr}_{0.92} \mathrm{Y}_{0.08} \mathrm{O}_{2-\delta}$ (YSZ) or $\mathrm{Ce}_{0.9} \mathrm{Gd}_{0.1} \mathrm{O}_{2-\delta}$ (GDC) supports. Top. Catal. 2015, 58, 1228-1241. [CrossRef]

29. Nishihata, Y.; Mizuki, J.; Akao, T.; Tanaka, H.; Uenishi, M.; Kimura, M.; Okamoto, T.; Hamada, N. Self-regeneration of a Pd-perovskite catalyst for automotive emissions control. Nature 2002, 418, $164-167$. [CrossRef]

30. Morgan, K.; Goguet, A.; Hardacre, C. Metal redispersion strategies for recycling of supported metal catalysts: A perspective. ACS Catal. 2015, 5, 3430-3445. [CrossRef]

31. Nagai, Y.; Dohmae, K.; Ikeda, Y.; Takagi, N.; Tanabe, T.; Hara, N.; Guilera, G.; Pascarelli, S.; Newton, M.A.; Kuno, O.; et al. In situ redispersion of platinum autoexhaust catalysts: An on-line approach to increasing catalyst lifetimes? Angew. Chem. Int. Ed. 2008, 47, 9303-9306. [CrossRef] [PubMed]

32. Tanabe, T.; Nagai, Y.; Dohmae, K.; Sobukawa, H.; Shinjoh, H. Sintering and redispersion behavior of Pt on Pt/MgO. J. Catal. 2008, 257, 117-124. [CrossRef]

33. Tanabe, T.; Morikawa, A.; Hatanaka, M.; Takahashi, N.; Nagai, Y.; Sato, A.; Kuno, O.; Suzuki, H.; Shinjoh, H. The interaction between supported $\mathrm{Rh}$ - and $\mathrm{Nd}_{2} \mathrm{O}_{3}$-enriched surface layer on $\mathrm{ZrO}_{2}$ for $\mathrm{Rh}$ sintering suppression. Catal. Today 2012, 184, 219-226. [CrossRef]

34. Morikawa, A.; Tanabe, T.; Hatanaka, M.; Takahashi, N.; Sato, A.; Kuno, O.; Suzuki, H.; Shinjoh, H. Inhibition of Rh sintering and improved reducibility of $\mathrm{Rh}$ on $\mathrm{ZrO}_{2}$ nanocomposite with an $\mathrm{Al}_{2} \mathrm{O}_{3}$ diffusion barrier. Appl. Catal. A 2015, 493, 33-39. [CrossRef]

35. Cao, Y.; Ran, R.; Wu, X.-Y.; Wu, X.-D.; Wan, J.; Weng, D. Ageing resistance of rhodium supported on $\mathrm{CeO}_{2}-\mathrm{ZrO}_{2}$ and $\mathrm{ZrO}_{2}$ : Rhodium nanoparticle structure and Rh-support interaction under diverse ageing atmosphere. Catal. Today 2017, 281, 490-499. [CrossRef]

36. Zhao, B.; Ran, R.; Cao, Y.; Wu, X.; Weng, D.; Fan, J.; Wu, X. Insight into the effects of different ageing protocols on $\mathrm{Rh} / \mathrm{Al}_{2} \mathrm{O}_{3}$ catalyst. Appl. Surf. Sci. 2014, 308, 230-236. [CrossRef]

37. Sing, K.S.W.; Everett, D.H.; Haul, R.A.W.; Moscou, L.; Pierotti, R.A.; Rouquerol, J.; Siemieniewska, T. Reporting physisorption data for gas/solid systems with special references to the determination of surface area and porosity. Pure Appl. Chem. 1985, 57, 603-619. [CrossRef]

38. Lan, L.; Chen, S.; Zhao, M.; Gong, M.; Chen, Y. The effect of synthesis method on the properties and catalytic performance of $\mathrm{Pd} / \mathrm{Ce}_{0.5} \mathrm{Zr}_{0.5} \mathrm{O}_{2}-\mathrm{Al}_{2} \mathrm{O}_{3}$ theree-way catalyst. J. Mol. Catal. A Chem. 2014, 394, 10-21. [CrossRef]

39. Zhou, Y.; Cheng, X.; Li, S.; Xiong, L.; Yan, S.; Wang, J.; Chen, Y. Promotional effect of alkyl acids on thermal stability of nanostructured $\mathrm{CeO}-\mathrm{ZrO}_{2}-\mathrm{Y}_{2} \mathrm{O}_{3}-\mathrm{La}_{2} \mathrm{O}_{3}$ and its application in automotive three-way catalysts. Mater. Sci. Eng. B 2017, 225, 10-19. [CrossRef]

40. Chen, H.; Ye, Z.; Cui, X.; Shi, J.; Yan, D. A novel mesostructured alumina-ceria-zirconia tri-component nanocomposite with high thermal stability and its trhree-way catalysis. Microporous Mesoporous Mater. 2011, 143, 368-374. [CrossRef]

41. Fornasiero, P.; Di Monte, R.; Ranga Rao, G.; Kaspar, J.; Meriani, S.; Trovarelli, A.; Graziani, M. Rh-Loaded $\mathrm{CeO}_{2}-\mathrm{ZrO}_{2}$ Solid-Solutions as Highly Efficient Oxygen Exchangers: Dependence of the Reduction Behavior and the Oxygen Storage Capacity on the Structural-Properties. J. Catal. 1995, 151, 168-177. [CrossRef]

42. Ozawa, M.; Takahashi-Morita, M.; Kobayashi, K.; Haneda, M. Core-shell type ceria zirconia support for platinum and rhodium three way catalysts. Catal. Today 2017, 281, 482-489. [CrossRef] 
43. Yentekakis, I.V.; Goula, G.; Hatzisymeon, M.; Betsi-Argyropoulou, I.; Botzolaki, G.; Kiousi, K.; Kontarides, D.I.; Taylor, M.J.; Parlett, C.M.A.; Osatiashtiani, A.; et al. Effect of support oxygen storage capacity on the catalytic performance of Rh nanoparticles for $\mathrm{CO}_{2}$ reforming of methane. Appl. Catal. B 2019, 243, 490-501. [CrossRef]

44. Morikawa, A.; Suzuki, T.; Kanazawa, T.; Kikuta, K.; Suda, A.; Shinjo, H. A new concept in high performance ceria-zirconia oxygen storage capacity material with $\mathrm{Al}_{2} \mathrm{O}_{3}$ as a diffusion barrier. Appl. Catal. B Environ. 2008, 78, 210-221. [CrossRef]

45. Silva, F.A.; Martinez, D.S.; Ruiz, J.A.C.; Mattos, L.V.; Hori, C.H.; Noronha, F.B. The effect of the use of cerium-doped alumina on the performance of $\mathrm{Pt} / \mathrm{CeO}_{2} / \mathrm{Al}_{2} \mathrm{O}_{3}$ and $\mathrm{Pt} / \mathrm{CeZrO} \mathrm{Zl}_{2} / \mathrm{Al}_{2} \mathrm{O}_{3}$ catalysts on the partial oxidation of methane. Appl. Catal. A Gen. 2008, 335, 145-152. [CrossRef]

46. Vayenas, C.G.; Brosda, S.; Pliangos, C. The double-layer approach to promotion, electrocatalysis, electrochemical promotion, and metal-support interactions. J. Catal. 2003, 216, 487-504. [CrossRef]

47. Vayenas, C.G.; Bebelis, S.; Yentekakis, I.V.; Lintz, H.-G. Non-faradaic electrochemical modification of catalytic activity: A status report. Catal. Today 1992, 11, 303-438. [CrossRef]

48. Montini, T.; Melchionna, M.; Monai, M.; Fornasiero, P. Fundamentals and catalytic applications of $\mathrm{CeO}_{2}$-based materials. Chem. Rev. 2016, 116, 5987-6041. [CrossRef]

49. Crookes, W. The volatility of metals of the platinum group. Proc. R. Soc. A Math. Phys. Eng. Sci. 1912, 86. [CrossRef]

50. Carol, L.A.; Mann, G.S. High-temperature oxidation of rhodium. Oxid. Met. 1990, 34, 1-12. [CrossRef]

51. Powell, A.R. Behaviour of the platinum metals at high temperatures. Platin. Met. Rev. 1958, 2, 96-98.

52. Li, P.; Chen, X.; Li, Y.; Schwank, J.W. A review on oxygen storage capacity of $\mathrm{CeO}_{2}$-based materials: Influence factors, measurement techniques, and applications in reactions related to catalytic automotive emissions control. Catal. Today 2019, 327, 90-115. [CrossRef]

53. Yang, T.; Xia, D. Self-combustion synthesis and oxygen storage properties of mesoporous gadolinia-doped ceria nanotubes. Mater. Chem. Phys. 2010, 123, 816-820. [CrossRef]

(C) 2019 by the authors. Licensee MDPI, Basel, Switzerland. This article is an open access article distributed under the terms and conditions of the Creative Commons Attribution (CC BY) license (http://creativecommons.org/licenses/by/4.0/). 